\begin{tabular}{|c|c|c|c|c|c|}
\hline MUNIBE Antropologia-Arkeologia & $n^{\circ} 72$ & $123-140$ & DONOSTIA & 2021 & ISSN 1132-2217 • eISSN 2172-4555 \\
\hline
\end{tabular}

\title{
Child burials in domestic contexts at an Iron Age hillfort: The Oppidum of Monte Bernorio (Villarén, Palencia)
}

\author{
Enterramientos infantiles en contextos domésticos en un castro \\ de la Edad del Hierro: El Oppidum de Monte Bernorio (Villarén, Palencia)
}

KEY WORDS: Osteoarcheology, bioarcheology, archeotanatology, infant burials, Iron Age.

PALABRAS CLAVES: Osteoarqueología, bioarqueología, arqueotanatologia, enterramientos infantiles, Edad del Hierro.

GAKO-HITZAK: Osteoarkeologia, bioarkeologia, arkeotanatologia, haurren ehorzketak, Burdin Aroa.

\section{Silvia CARNICERO-CÁCERES(1), Jesús F. TORRES-MARTÍNEZ ${ }^{(2)}$}

\section{ABSTRACT}

The practice of child burials underneath house floors in the Late Prehistory has been considered a characteristic trait of the Iberian religion. However, this custom has also been documented in different archaeological sites both in the Mediterranean and Central Europe as well as Celtic areas of the Iberian Peninsula, so we can explain this funerary practice by an Indo-European origin.

We report the archeotanatological and osteoarcheological study of 10 subadults found in the Iron Age site of Monte Bernorio oppidum, the first archeological site in the western and central Cantabrian region with this funerary rite documented. It is the confirmation of both, the survival of an ancient funerary ritual, widely extended in all Europe, and its presence in the north of the Iberian Peninsula.

We also review all the archeological sites in the Iberian Peninsula with similar archeological contexts and analyse the rite from the bioarcheology of the care.

\section{RESUMEN}

Durante años, la práctica de los enterramientos infantiles bajo el suelo de las viviendas en la Prehistoria Tardía ha sido considerada propia de la religión y ámbito ibérico Sin embargo, se ha documentando también en diferentes yacimientos de Europa Central y del ámbito céltico de la Península Ibérica., pudiendo explicarse debido a las raíces indoeuropeas de la misma.

Presentamos el estudio arqueotanatológico y osteoarqueológico de 10 sujetos infantiles hallados en el yacimiento de la Edad de Hierro del Oppidum de Monte Bernorio, el primer y único yacimiento de la zona occidental y central del Cantábrico con este tipo de restos publicados. Constituye la constatación de la pervivencia de un ritual funerario antiguo y ampliamente extendido en el espacio europeo, del que hasta ahora no se habían encontrado ejemplos en la esta área.

También se realiza una revisión de todos los yacimientos de la Península Ibérica con contextos similares y se analiza el rito desde la perspectiva de la bioarcheología del cuidado.

\section{LABURPENA}

Urte askoan, Historiaurre Berantiarrean haurrak etxebizitzen lurzoruaren azpian ehortzi izana erlijioarekin eta iberiarrekin lotu izan da. Dena den, Europa erdialdeko eta iberiar penintsulako eremu zeltikoko hainbat aztarnategitan ere dokumentatu izan da. Hori guztia iberiar penintsularen sustrai indoeuroparren ondorio izan daiteke.

Monte Bernorio mendiko Oppidumeko Burdin Aroko aztarnategian topatutako 10 haurren azterketa arkeotanatologikoa eta osteoarkeologikoa aurkeztu dugu. Era horretako aztarnak argitaratuta dituen Kantaurialdeko mendebaldeko eta erdialdeko eremuko aztarnategi bakarra da. Europa inguruan oso zabalduta zegoen antzinako hileta-erritual batek bizirik iraun izanaren froga izan da, orain arte eremu honetan ez baita horren inguruko adibiderik aurkitu.

Bestalde, antzeko testuinguruak dituzten iberiar penintsulako aztarnategi guztiak berrikusi eta erritua zainketaren bioarkeologiaren ikuspegitik aztertu da.

\footnotetext{
(1) Médico Forense. Máster en Antropología Física y Forense. Especialista en Anatomía Patológica. Instituto de Medicina Legal y ciencias Forenses de Cantabria. Avda. Pedro San Martín s/n. Santander. 39010. Cantabria. Spain. E-mail: aivlisxii@yahoo.es. ORCID: 0000-0003-4887-8907. (2) Instituto Monte Bernorio de Estudios de la Antigüedad. Universidad Complutense de Madrid. E-mail: ketxutorres@yahoo.com. ORCID: 00000003-4714-1567.
} 


\section{INTRODUCTION}

For a long time archeology has interpreted funerary spaces by the material culture recovered, not through the study of the people buried. The poor conservation of the human remains, the difficult recovery and the lack of trained professionals contributed to the loss of much relevant information about past societies. In recent years, due the appearance of osteoarcheology and physical anthropology studies in archaeological contexts reversed this situation, except for the remains of subadult individuals. Their greater fragility and the scarce presence of grave goods have conditioned the investigations on this age group (De Miguel, 2010). However, in recent years a growing number of studies about child burials has been published, reflecting the greater awareness and level of preparation of the archaeologists who excavate contexts with human remains.

We present the study of ten infantile subjects, most of them perinatals, found during successive archaeological seasons (2006, 2007, 2013 and 2016) at the site of Monte Bernorio oppidum. They are the first remains reported in a domestic context in the north of the Iberian Peninsula, as well as for the chronological period, the Iron Age. A significant discovery, since it confirms the existence of this ritual, traditionally associated with the Iberian and Mediterranean sphere (reviewed in this article), in this geographical area.

Our reported serie is unique, since there no other skeletal remains have been recovery, due to the generalized funerary practices (cremation). Furthermore, the deep analysis of this ritual using archeothanatological and bioarcheology of the care perspectives gives a lot of information about care giving and social consideration of the weakest subjects of this society even in the life after death.

This is the first reported results of the multidisciplinary study we are carrying through this remains, in order to know more about the Iron Age society settled in the Cantabrian Mountains.

\section{PREHISTORIC INFANT BURIALS. DOMESTIC BURIALS}

Regarding late Prehistory, the funerary practice used from the Neolithic and during the Chalcolithic was collective burials in megalithic constructions. At the end of the Chalcolithic and Initial Bronze Age, individual burials became generalized. Infant remains are recovered in all of them, so it is assumed no ritual differences due to age. At the final Bronze Age the ritual of the cremation became generalized and continued throughout the Iron Age and a large part of the Hispano-Roman Era (Fábregas \& Ruiz-Gálvez, 1994; Teira, 1994; Fábregas, 1995; Delibes et al., 1999; González Morales, 1999; Stefanović \& Borić, 2008; Pellicer, 2008; Bettencourt, 2010a, 2010b; Lorrio et al., 2010; Gusi, 2011; Gusi \& Luján, 2011; Torres-Martínez et al., 2012). In the Canta- brian area are few studies of cremation necropolis (Torres-Martinez, 2011; Torres-Martínez et al., 2018), none with osteoarcheological perspective, so it is not possible to know if children suffered this ritual or not.

Despite this ritual, there are numerous examples of child burials in domestic contexts in the Iberian Peninsula from Bronze Age through the Iron Age (table 2). Although it was considered a cultural phenomenon native to the Iberian area with Phoenician influences (Pellicer, 2008), it is a common practice in the Indo-European "world" (Gracia, 1989; Prados, 2011; De Miguel, 2006) (Table 1). In fact, domestic infantile burials have been detected in the east of the Cantabrian area, in the hillforts of the Upper and Middle basin of the Ebro. (Table 2), (Maluquer, 1958; Maluquer et al., 1990; Mercadal et al., 1990; Llanos, 1990, 2002, 2005; Filloy, 1995; Etxeberria-Herrasti, 1995; Ruiz Gálvez, 1998; Galilea-García, 2002; Armendáriz, 1996; Armendáriz-De Miguel, 2006; Armendáriz, 2007; Fernández-Crespo, 2008; Gusí-Muriel, 2008) although there are not extensive osteoarcheological studies reported. In the central Cantabrian area, there are no infant burials in domestic areas published, excepting these from Monte Bernorio oppidum. Although two fetal tibiae were detected in La Campa Torres (Gijon, Asturias) (Mercadal, 2001), there are no archeological reports of the find to contextualize them. Nevertheless, the number of burials is insufficient related to the high child mortality rates associated with these populations, so we must consider other types of funerary rituals for subadult individuals (De Miguel, 2006, 2010).

Regarding the motivations of the election of this type of ritual, archeologists suggest four hypotheses for the burial of children in the domestic environment (Gusí \& Muriel, 2008): consequence of natural death, religious sacrifice, infanticide as demographic control or abandonment of an unwanted infant. Despite the difficulties in the interpretation of certain rituals performed in the past, for most authors these burials in the domestic sphere would have a symbolic and protective value, since children need the protection of the home and family in their journey to the underworld (Stefanović \& Borić, 2008). In Armendariz and De Miguel words: "favor their return to the womb for rebirth from the afterlife through the telluric womb".

\section{THE OPPIDUM OF MONTE BERNORIO}

The oppidum of Monte Bernorio is located on the top of the homonym mountain at $1,173 \mathrm{~m}$ altitude in the municipality of Pomar de Valdivia (Palencia) (Fig. 1)

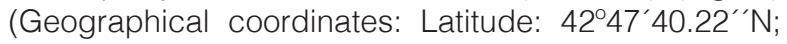
Longitude: $4^{\circ} 11^{\prime} 43.91^{\prime \prime W}$. Ministry of Agriculture of Spain). The first studies at this site were carried out in 1880 (Gutiérrez \& Hierro, 2010); in 1890, one of the necropolises and the 'Monte Bernorio' type daggers were found and the first archaeological excavations took place in 1943, 1944 and 1959. The site was abandoned until the current research project started in 2004. 


\begin{tabular}{|c|c|c|c|c|}
\hline SITE & PERIOD & ANTHROPOLOGICAL STUDY & MNI & AGES \\
\hline $\begin{array}{l}\text { Alto de la Cruz } \\
\text { (Cortes, Navarra) }\end{array}$ & Late Bronze Age & $\begin{array}{l}\text { 1990. MERCADAL, CAMPILLO, } \\
\text { PEREZ-PEREZ }\end{array}$ & 9 & $\begin{array}{l}\text { Preterm: } 2 \\
\text { Fullterm: } 7 \\
\text { 6-12: } 1 \\
>12: 12\end{array}$ \\
\hline Peñahitero (Fitero, NAvarra) & Iron Age & 1965. MALUQUER de lo MONTES & & \\
\hline Atxa (Vitoria-Álava) & $\begin{array}{c}\text { Iron Age } \\
\text { (5th-3rd centuries BC) }\end{array}$ & $\begin{array}{l}1995 \text { GIL. ETXXEBERRIA, } \\
\text { HERRASTI, GIL }\end{array}$ & 49 & $\begin{array}{l}\text { Preterm: } 10 \\
\text { Fullterm: } 28 \\
<6: 5 \\
6-12: 4 \\
>12: 2\end{array}$ \\
\hline Zaragoza & Iberian & 1997. FATAS, BEIRAC & 1 & \\
\hline Vicamest (Fraga, Huesca) & 10th century BC & 2005. MOYA, LÓPEZ & 1 & neonatal \\
\hline La Hoya A (Álava) & Late Bronze Age & 2002. GALILEA Y GARCÍA & 131 & $\begin{array}{l}\text { Preterm: } 20 \\
\text { Fullterm: } 90 \\
<6: 48 \\
6-12: 14 \\
>12: 12\end{array}$ \\
\hline La Hoya B (Álava) & Iron Age & & 49 & \\
\hline Las Eretas (Berbinzana, Navarra) & Iron Age & 2006. DE MIGUEL & 6 & $\begin{array}{l}\text { Preterm: } 2 \\
\text { Fullterm: } 3 \\
<6: 1\end{array}$ \\
\hline Libia (La Rioja) & Iron Age & No localizado estudio & & \\
\hline El Castejón (Barbota. Navarra) & Iron Age & 2000. DE MIGUEL & 2 & Fullterm (few days) \\
\hline Cerro de Santa Barbara (Tudela, Navarra) & & No localizado estudio & 1 & \\
\hline El Castillar (Mendavia.Navarra) & & 1986. MARIZCURRENA & $\begin{array}{l}\text { Small bones among } \\
\text { fauna remains }\end{array}$ & \\
\hline Cerrocuquillo (Villaluenga de la Sagra. Toledo) & Early Iron Age & 2010. TORIJA & 10 & Neonatal \\
\hline
\end{tabular}

Tabla 1: Archeological sites with child burials in domestic contexts in the Iberian Peninsula (Indo-European-Celtic area). / Yacimientos arqueológicos con inhumaciones infantiles en contextos domésticos en la Península Ibérica (área Indoeuropea-céltica).

\begin{tabular}{|c|c|c|c|c|}
\hline SITE & PERIOD & ANTHROPOLOGICAL STUDY & MNI & $\overline{\text { AGES }}$ \\
\hline Els Estinclells (Verdú, Lleida) & & 2006. MURIEL ASENSIO & 1 & \\
\hline $\begin{array}{l}\text { Moleta del Remei } \\
\text { (Alcanar. Montsia. Tarragona) }\end{array}$ & $\begin{array}{l}\text { Late 5th - early 3rd } \\
\text { centuries BC }\end{array}$ & 1989. GRACIA, CAMPÌLLO & $5+1$ in the rocks & Perinatal: 5 \\
\hline Castellet de Barnabé (Valencia) & 4th century BC & 1988. GUERIN & 1 & Fullterm \\
\hline La Seña (Valencia) & & 1988. GUERIN & 3 & Fullterm \\
\hline Puntals dels Llops (Valencia) & & 1988. GUERIN & 1 & Fullterm \\
\hline Los Villares (Valencia) & & 1988. GUERIN & 1 & \\
\hline La Escudilla (Castellón) & & 1989. GUSI & $29(25+3)$ & Neonatal \\
\hline Los cabañiles (Castellón) & & 1989. GUSI 2006: FALOMIR Y MURIEL & 6 & Neonatal \\
\hline Penya del Moro (Sant Just Desven. Barcelona) & 7th -6 th centuries BC & 1989- BARBERA & 4 & Fullterm \\
\hline Sant Miguel (Turia. Valencia) & $\begin{array}{l}\text { Late } 5 \text { th -early 4th } \\
\text { centuries BC }\end{array}$ & 1995. CALVO & 6 & \\
\hline Els ostrets Racó de Rata (Vilafamés. Castellón) & Iberian & 1996. MAJÓ & 2 & $<6(2$ y $2 / 5 \mathrm{~m})$ \\
\hline Huelva & 6th century BC & 1996. MALGOSA, ALUJA, ISIDRO & 1 & Preterm \\
\hline Ca N'olivé (Cerdayoles del vallés. Barcelona) & & 1999. MERCADAL & & \\
\hline Els villars (Arbeca. Lleida) & Early Iron Age & 2000. AGUSTí et. al. & $6(1,1,3)$ & $\begin{array}{l}\text { Preterm. } 1 \\
\text { Fullterm: } 4\end{array}$ \\
\hline Els Camps de les Lloses (Tora. Barcelona) & & 2000. ÁLVAREZ, DURÁN Y LÓPEZ & 2 & \\
\hline Puig Castellar (Sta. Coloma Gramanet. Barcelona) & & 2003. MURIEL & 6 & \\
\hline Puig de la Nau (Benicarló. Castellón) & & 2006. OLIVER & & \\
\hline Oppidum El Molón (Camporrobles. Valencia) & $\begin{array}{l}\text { Iron Age. } \\
\text { 2nd Century BC }\end{array}$ & 2010 LORRIO, DE MIGUEL, et al. & $\begin{array}{l}4 \text { (1, with } \\
2 \text { bodies) }\end{array}$ & $\begin{array}{l}\text { Preterm: } 2 \\
\text { Fullterm: } 1 \\
\text { "Few days": } 1\end{array}$ \\
\hline $\begin{array}{l}\text { Bajil (Moratalla), Los cipreses (Lorca), } \\
\text { Madres Mercedarias (Lorca. Murcia) }\end{array}$ & Bronze Age & 2015. RODRIGUEZ GONZALEZ & 18 & \\
\hline
\end{tabular}

Tabla 2: Archeological sites with child burials in domestic contexts in the Iberian Peninsula (Iberian and Turdetanian areas). / Yacimientos arqueológicos con inhumaciones infantiles en contextos domésticos en la Península Ibérica (área lbérica y turdetana). 


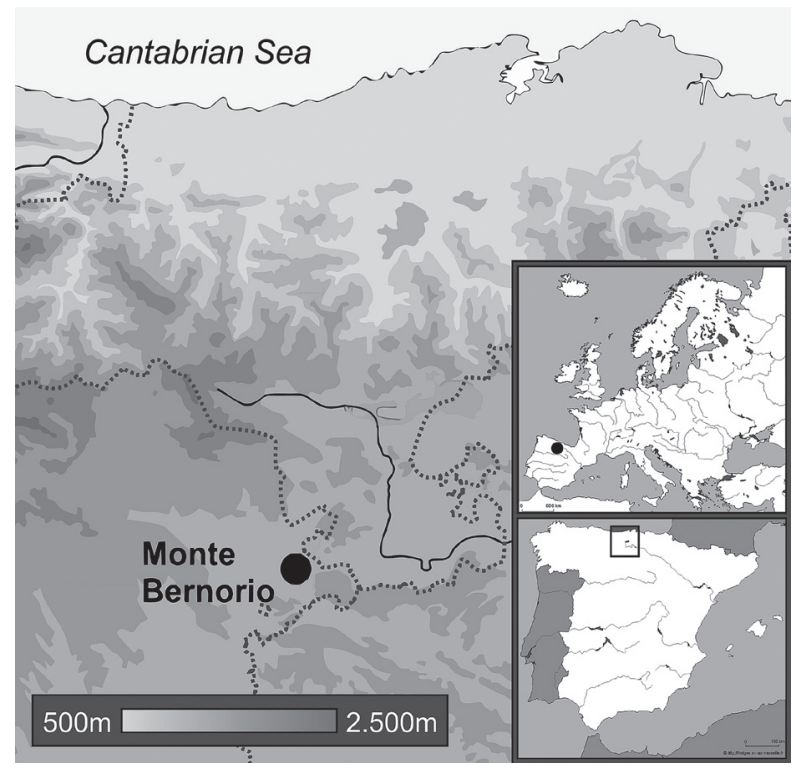

Fig.1. Situation of Monte Bernorio oppidum (infographic by J. F. Torres-Martínez and M. Galeano Prados, Monte Bernorio IMBEAC Team). / Situación del oppidum de Monte Bernorio (Infografía de J. F. Torres-Martínez y M. Galeano Prados, Equipo Monte Bernorio IMBEAC).
The oppidum is on a large limestone tooth-shaped plateau, an outstanding strategic position at the intersection of a number of natural communication routes. The defensive wall is about $1,700 \mathrm{~m}$, with three fortified gates, which creates an inner space of about 28 ha, and is reinforced by concentric lines of earthworks and ditches in a multi-walled type of defensive system comprising a total area of more than 90 ha. around the oppidum. (Torres-Martínez \& Martínez, 2012A; Torres-Martínez et al., 2013). (Fig. 2). There are several necropolises both, inside and outside the defensive system.

\section{THE LOCATION OF THE CHILD REMAINS}

In the south flank wall, next to the southern gate, two big rectangular structures with rounded corners were built over some previous buildings dated to the beginning of the Early Iron Age. (Fig. 3). Both underwent several reforms or rebuilds always in the same space. The radiocarbon date $\left(\mathrm{C}^{14}\right)$ obtained in Building 1 established a 5th century BC date $(2428 \pm 34 \mathrm{BP})$ for the foundation level. Both were destroyed at the time of the Roman conquest (late 1st century BC).

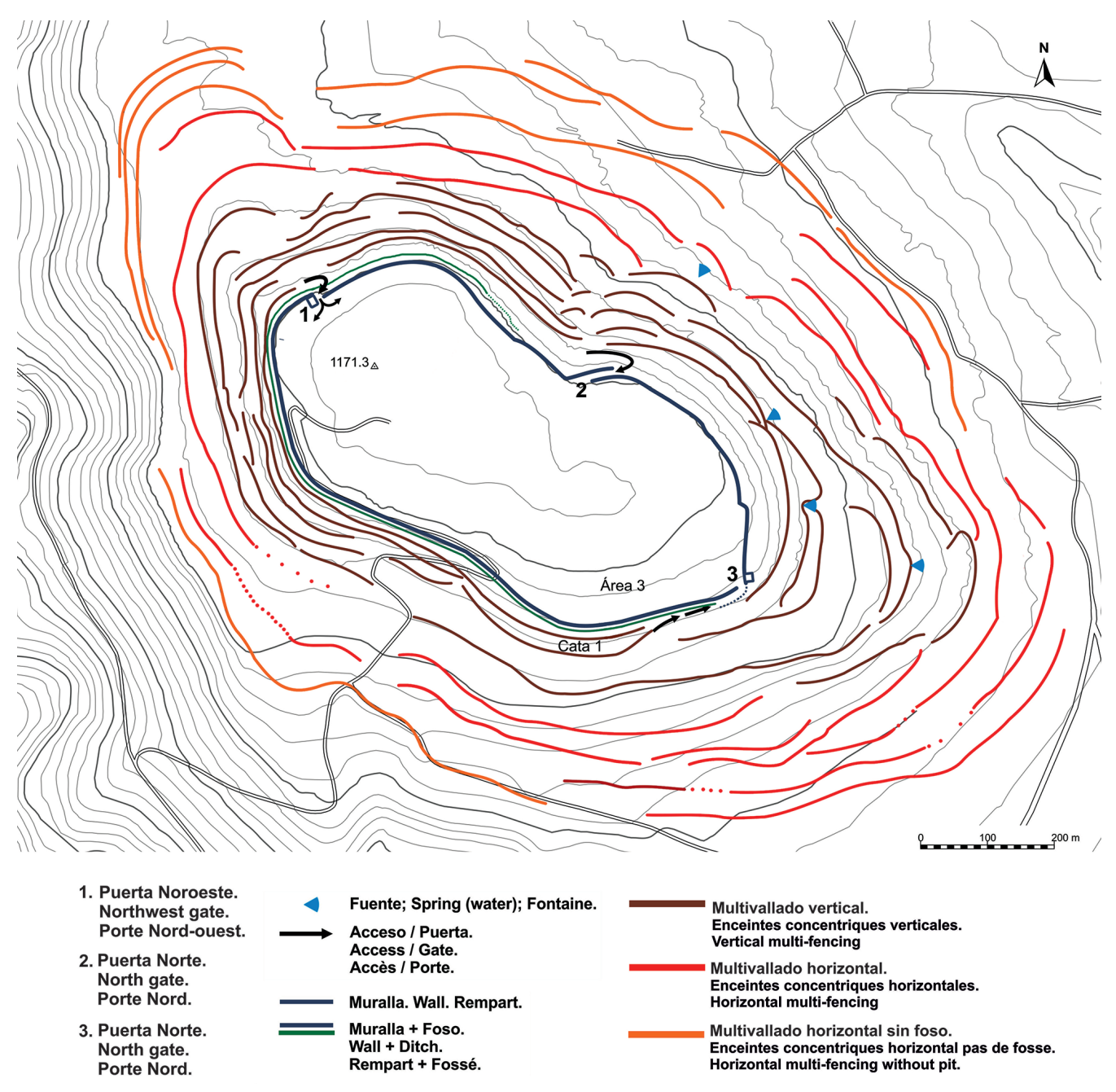

Fig.2. Plan of Monte Bernorio oppidum (infographic by J. F. Torres-Martínez and M. Galeano Prados, Monte Bernorio IMBEAC Team). I Plano del oppidum de Monte Bernorio (Infografía de J. F. Torres-Martínez y M. Galeano Prados, Equipo Monte Bernorio IMBEAC). 


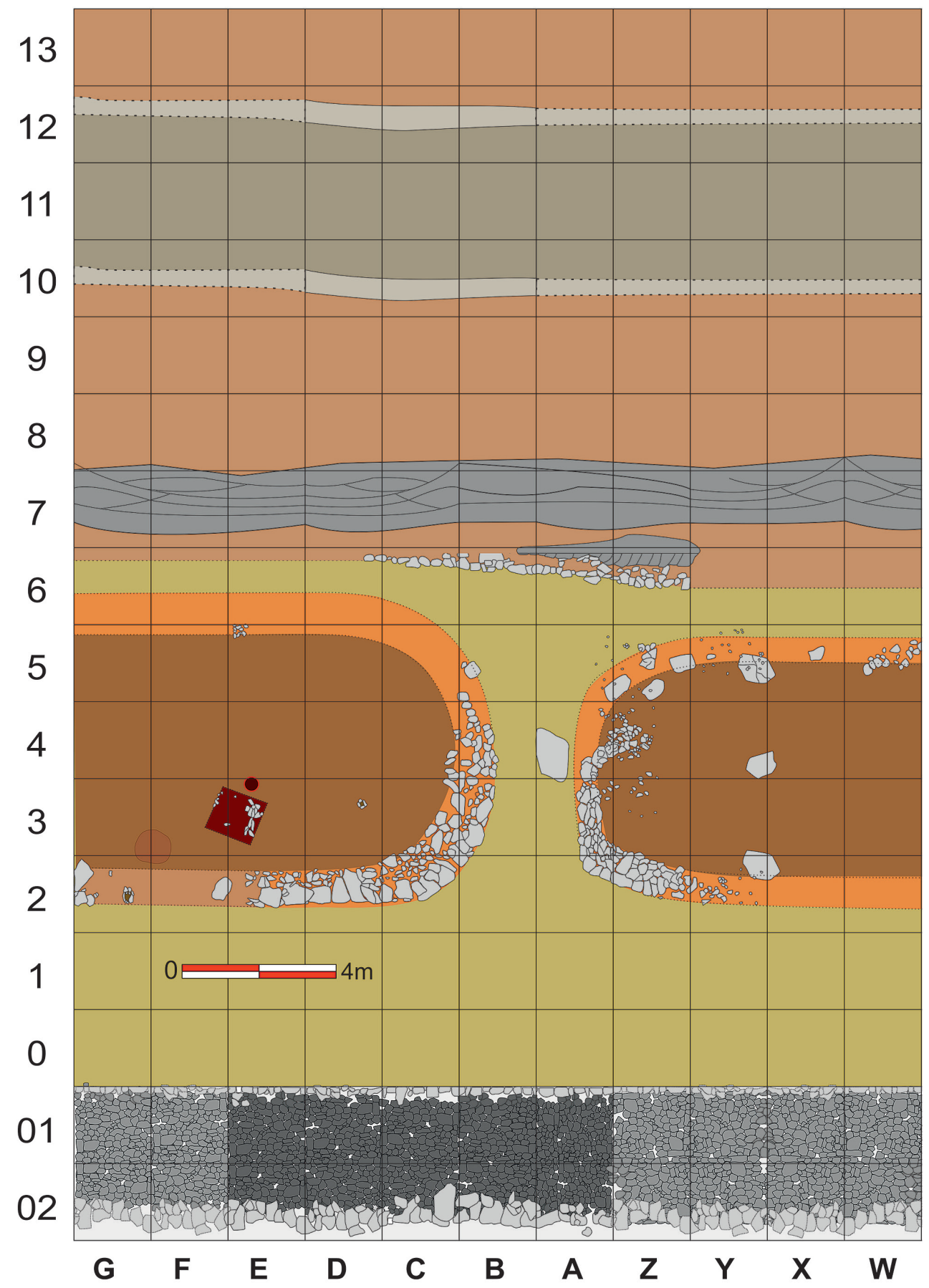

Fig.3. Plan of Monte Bernorio oppidum Area 3 with the location of Buildings 1 and 2, their surrounding areas and a section of the southern wall (infographic by J. F. Torres-Martínez and M. Galeano Prados, Monte Bernorio Team IMBEAC). ( Plano del Área 3 del oppidum de Monte Bernorio con la situación de los Edificios $\mathrm{N}^{\circ}$ 1y $\mathrm{N}^{\circ} 2$, sus zonas adyacentes y el tramo de la muralla sur (Infografía de J. F. Torres-Martínez y M. Galeano Prados, Equipo Monte Bernorio IMBEAC).
Perinatal remains were found underneath the floor of both buildings:

- In Building 1, in the center of the construction, next to the door and fire area (Fig. 4).

- In Building 2, under the building floor, on the west side, towards one of the end points of the construction. (Fig. 4). The remains were collected in two sets, and buried again, likely in a reconstruction of the building.

\section{OSTEOARCHEOLOGICAL AND ARCHAEOTA- NATOLOGICAL STUDY}

\subsection{Material and methods}

Two infant skeletal remains (MB 1/2006 and MB $1 / 2007$ ) were identified during the excavation and the anthropological study was performed and reported (Torres-Martínez et al., 2012). In 2016 other bone remains were recovered; four subjects (MB 1/2016, MB 2/2016, MB 3/2016, MB 4/2016) were identified. In 2019, the ar- 

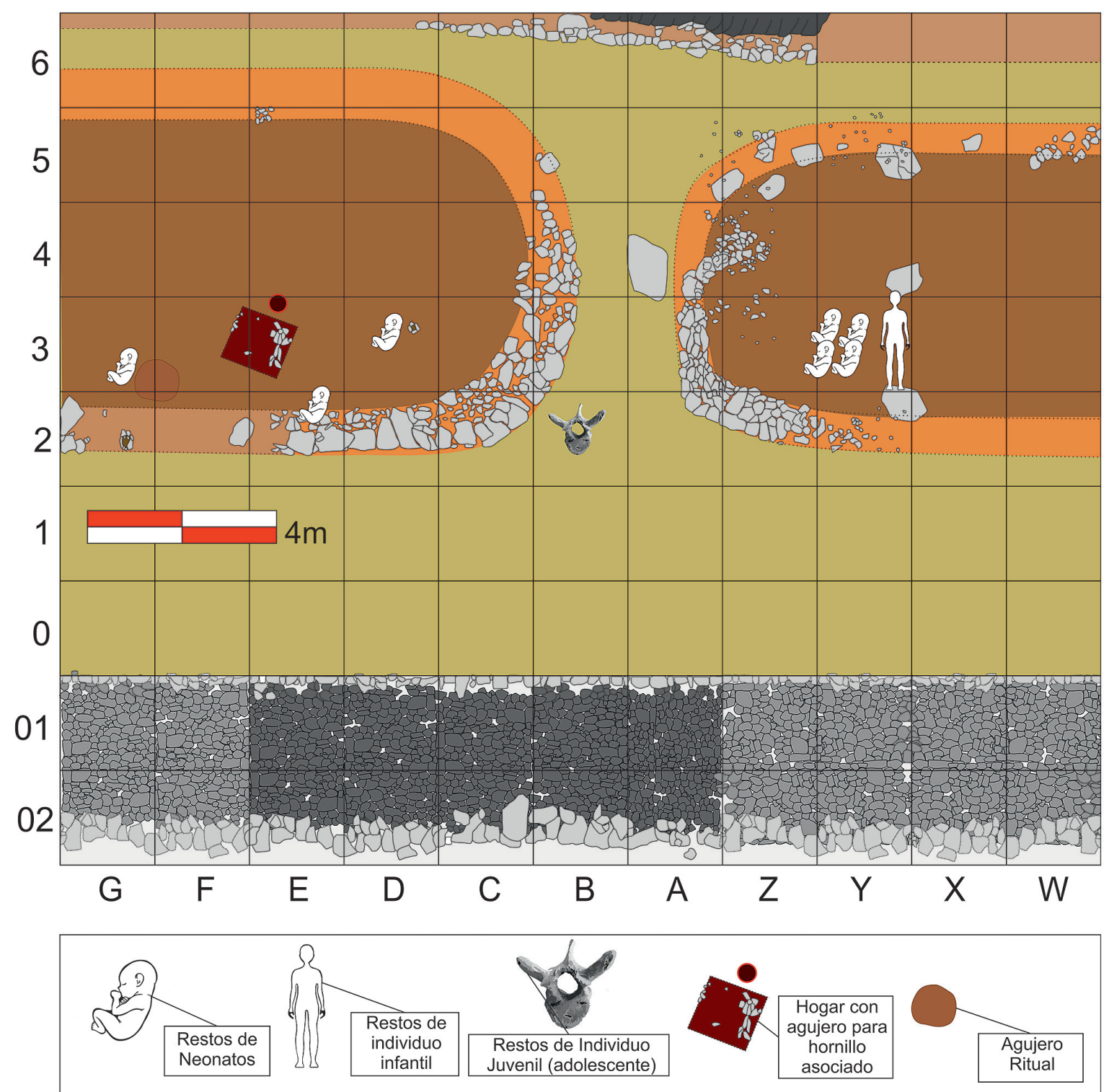

Fig.4. Plan of the Monte Bernorio oppidum Area 3 with Buildings 1 and 2, and the situation of the perinates and child remains. / Plano del Área 3 del oppidum de Monte Bernorio con los Edificios $\mathrm{N}^{\circ}$ y y $\mathrm{N}^{\circ} 2$ y los indicadores de la situación de los restos de neonatos e infantiles en ellos (Infografía de J. F. Torres-Martínez y M. Galeano Prados, Equipo Monte Bernorio IMBEAC).

cheological material was re-examined in order to take samples for complementary studies: Regarding the 2006 season, two other individuals (MB 2/2006 and MB 3/2006) were identified; concerning the 2007 fieldwork, MB 2/2007 was identified. In addition, MB 1/2013 was analyzed.

Bones were cleaned (soft brush and little water) and fragments were reversible joined, when necessary, with cellulose nitrate (Imedio blue band $®$ glue)

The anthropological study was based on the macroscopic inspection and measurement of the skeletal remains. Age has been established by comparing bone measurements with different collection data: Fazekas-Kossa (1978), Jeanty (1983), Scheuer (1980) or Scheuer-Black (2009). Ubelaker diagrams (1978) for dental eruption were also used. The age of fetal individuals is given in weeks of gestational age (WG), according to current gynecological terminology. The age groups used have been the seven proposed by White (2012). Regarding sex, although there are some published methods, such as Schutkowky (1997), or Weaver (1980), according to Scheuer \& Black (2000), sex identification is not reliable until the puberty bone modifications have started. Indeed, reviews of these methods in a Spanish population (Irurita \& Aleman, 2016) discourage their use because of the limited accuracy.

The taphonomic modifications were analyzed according to Fernández-Jalvo (2016). 


\subsection{Results}

\subsubsection{6 archeological season}

\subsubsection{MB-1/2006}

Location: Among the remains of a collapsed wall (SU 3), immediately below the foundation level (SU 4) of Building 1. (A3/T1/S. D2/SU 3-4).

Position: They were crushed with no anatomical relationship.

Conservation: Partial. Lower half. (Fig. 5)
Pathologies: No congenital conditions nor pathologies.

Taphonomy: Few root marks No marks of weathering or trampling are evident, nor color changes or scavenging marks. No marks made by insects, microorganism or even objects. Fractures are related to the process of excavation and manipulation, discarding the effect of trampling.

Sex: Undetermined

Age: 39-42 WG. Full-term fetus.
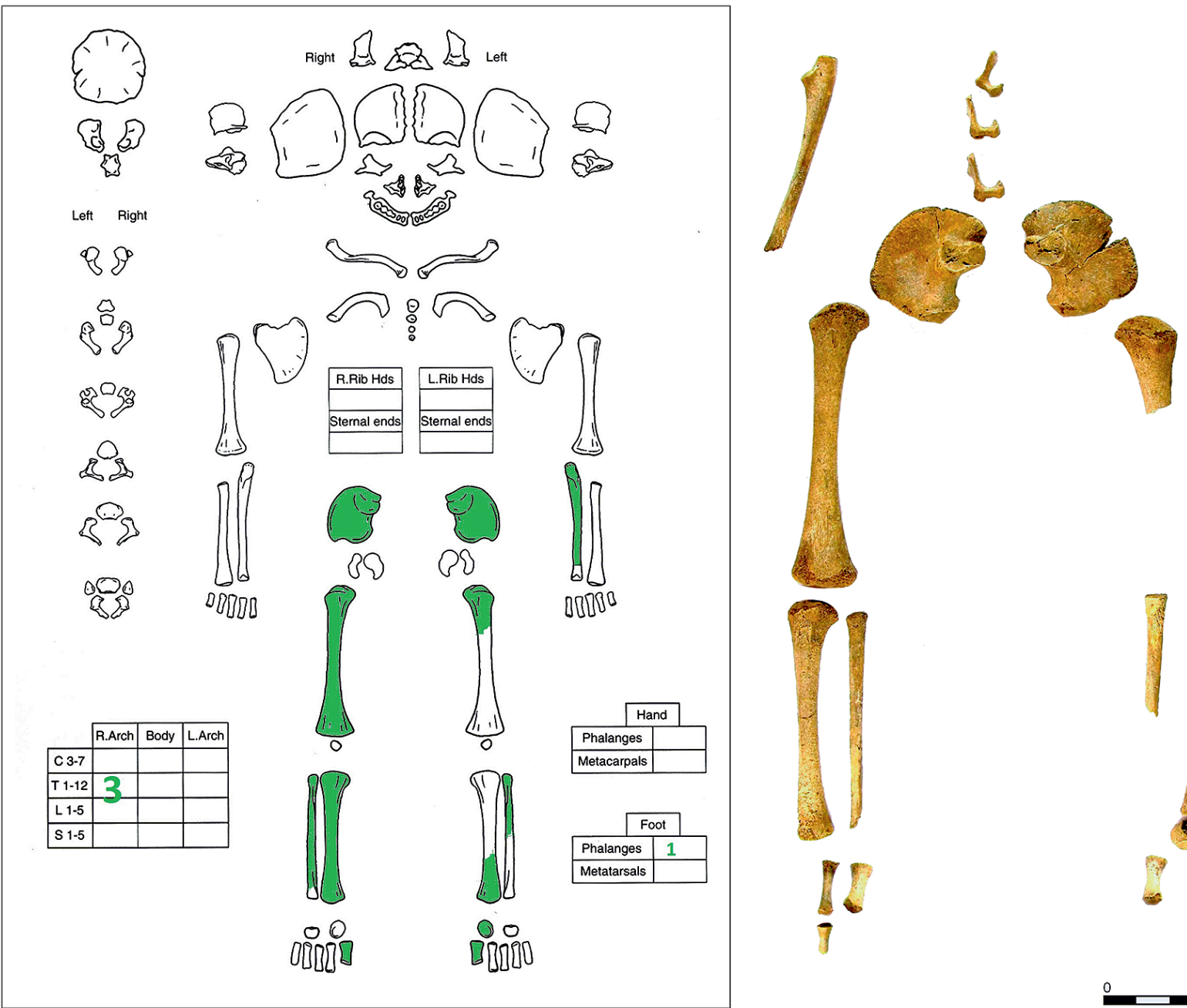

Fig.5. Skeletal remains of MB 1/2006. Right: paradigm, with the correct lateralization of the left ulna. / Restos esqueléticos de MB 1/2006. Derecha: paradigma, con la correcta lateralización del cúbito izquierdo. 


\subsubsection{MB-2/2006}

Location: Building 1. (A3/T1/S. D3/SU 2-3).

Position: Mingled with animal bones, with no anatomical relationship.

Conservation: Poor, with representation from all areas (Fig. 6).
Pathologies: None.

Taphonomy: Roots marks. Fractures made by compression of the sediment and/or human manipulation in the past.

Sex: Undetermined

Age: 40 WG, full-term.
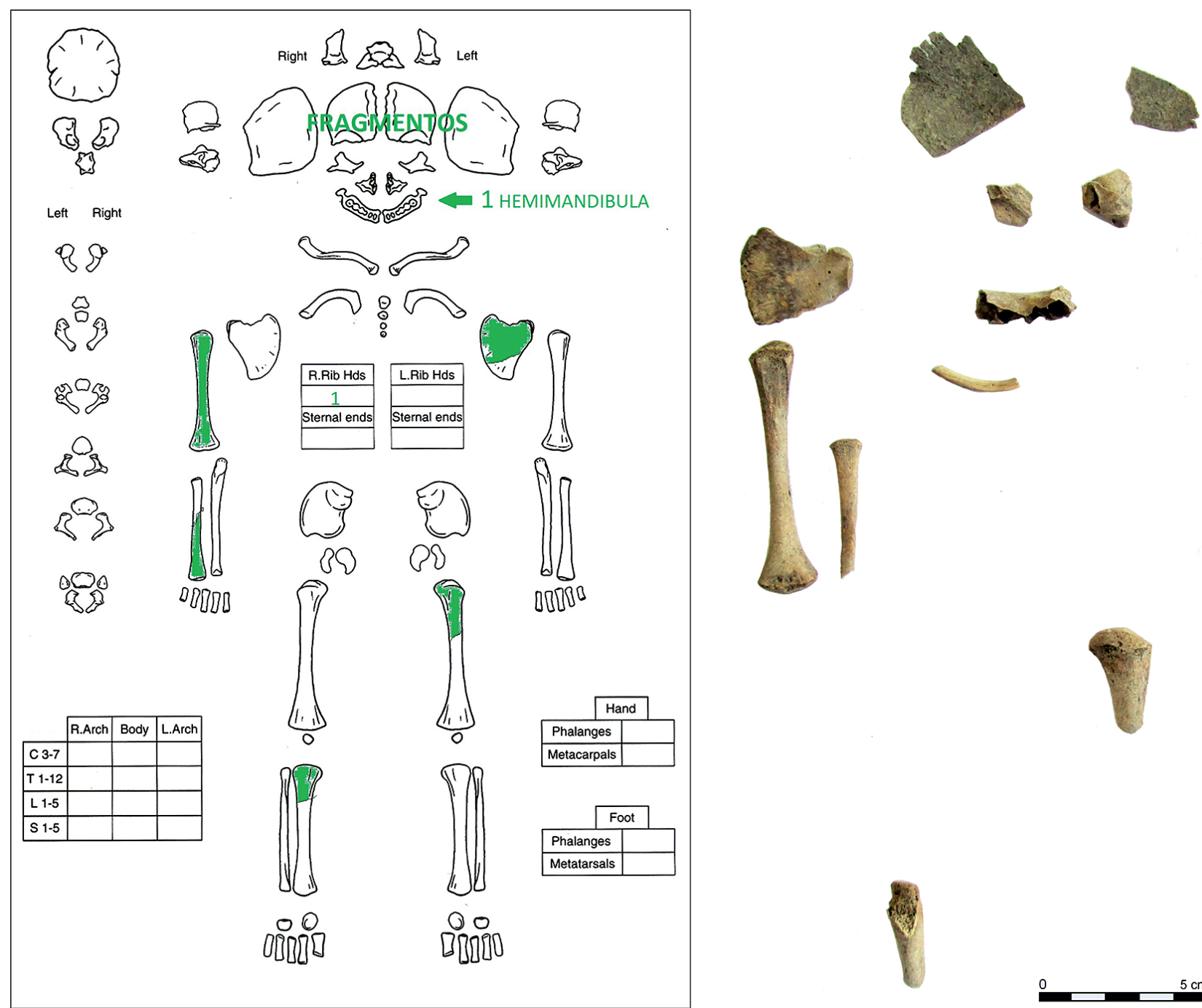

Fig.6. Skeletal remains of MB 2/2006. Right: paradigm, with the correct lateralization of the left scapula. / Restos esqueléticos de MB 2/2006. Derecha: paradigma, con la correcta lateralización de la escápula izquierda. 


\subsubsection{MB-3/2006}

Location: Building 1. (A3/T1/S.D2/SU 3).

Position: Same context MB 1/2006.

Conservation: 20\% (right upper limb and some bones)s (Fig. 7).
Pathologies: None

Taphonomy: Scarce root marks. Fractures, in dry bone.

Sex: Undetermined

Age: 38-40 WG. Full-term.
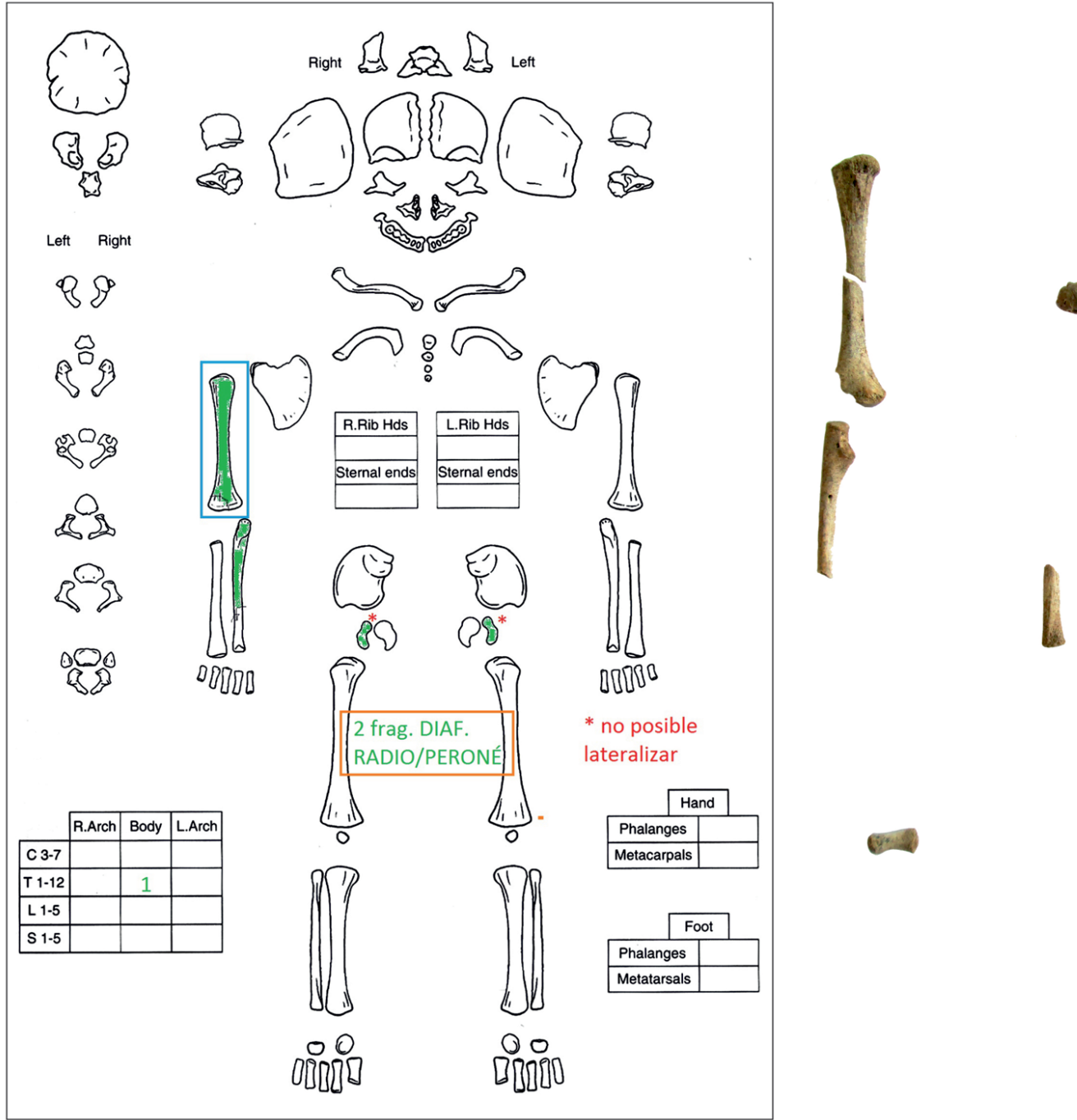

Fig.7. Skeletal remains of MB 3/2006. / Restos del sujeto MB 3/2006 


\subsubsection{7 archeological season}

\subsubsection{MB-1/2007}

Location: Among the remains of fired clay walls (pajabarro) amortized as fill to level the west side of Building 2 floor (A3/T1/S. Y3/SU 3).

Position: As part of a package without anatomical connection.
Conservation: $40 \%$ (upper half of the body, with representation of lower limbs). (Fig. 8)

Pathologies: None.

Taphonomy: Root marks and dry fractures.

Sex: Undetermined

Age: 38-40 WG. Full-term.
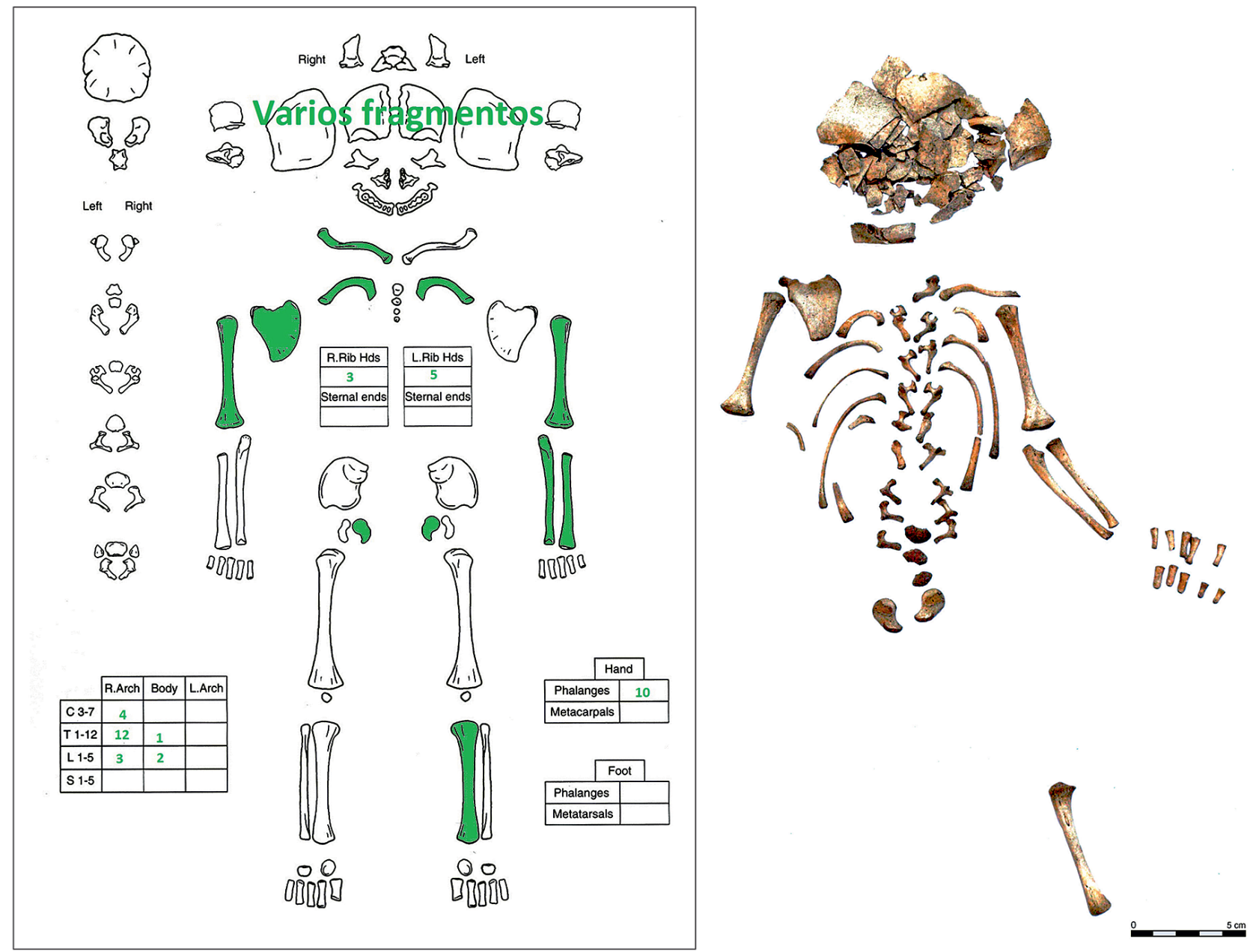

Fig.8. Skeletal remains of MB 1/2007. / Restos del sujeto MB 1/2007.

\subsubsection{MB-2/2007}

Location: Between Buildings 1 and 2, next to the defensive wall. (A3/T1/S B2/SU 3).

Position: Isolated.

Preserved bones: A subadult dorsal vertebra. (Fig. 9)

Taphonomy: Some losses of substance (friction).

Sex: Undetermined

Age: Between puberty and the early twenties.

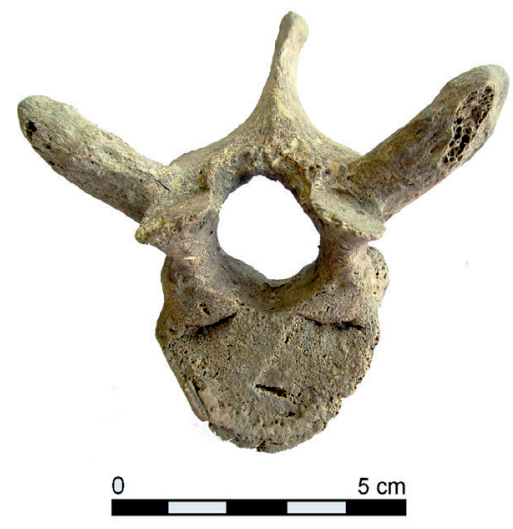

Fig.9. Dorsal vertebra of Individual MB 2/2007 in superior and inferior view. / Vértebra dorsal en visión superior e inferior del Sujeto MB 2/2007. 


\subsubsection{Archeological season: MB-2013}

Location: Surroundings of Building 1, near a space (¿door of the building?) (A3/T1/S. G2-G3/SU 3).

Conservation: 40\%. (Upper half of the body). (Fig. 10)

Pathologies: None.

Taphonomy: Roots marks. Dry fractures.

Sex: Undetermined

Age: 6 months-1 year of postnatal life.

\subsubsection{6 season}

4 subjects were recovered from a package. Bones were gathered long after the skeletonization of the bodies, occurred in a not discovered primary burial. Bones were gathered in two very close groups: Various fragments of different skulls had been placed to cover the rest of the skeletal remains*(Fig. 11). Their location was inside the landfill used to level Building 2 floor (A3/ T1/S. Y3, SU 203).

\subsubsection{MB-1/2016}

Conservation: 50\% -75\% (except left upper extremity)

Pathologies: None.

Taphonomy. Roots marks, dry bone fractures. The position of the bones indicates post-depositional anthropic manipulation*: the frontal bone was adjacent to the package formed by the rest of the cranial bones; in this package we identified bones of both MB1/2016 and MB2 /2016 (some bones of the skull base of MB 1/2016, as well as other long bones of both individuals). The occipital was under both frontals of MB 2/2016.

Sex: Undetermined

Age: 38 WG (range 36-40 WG).
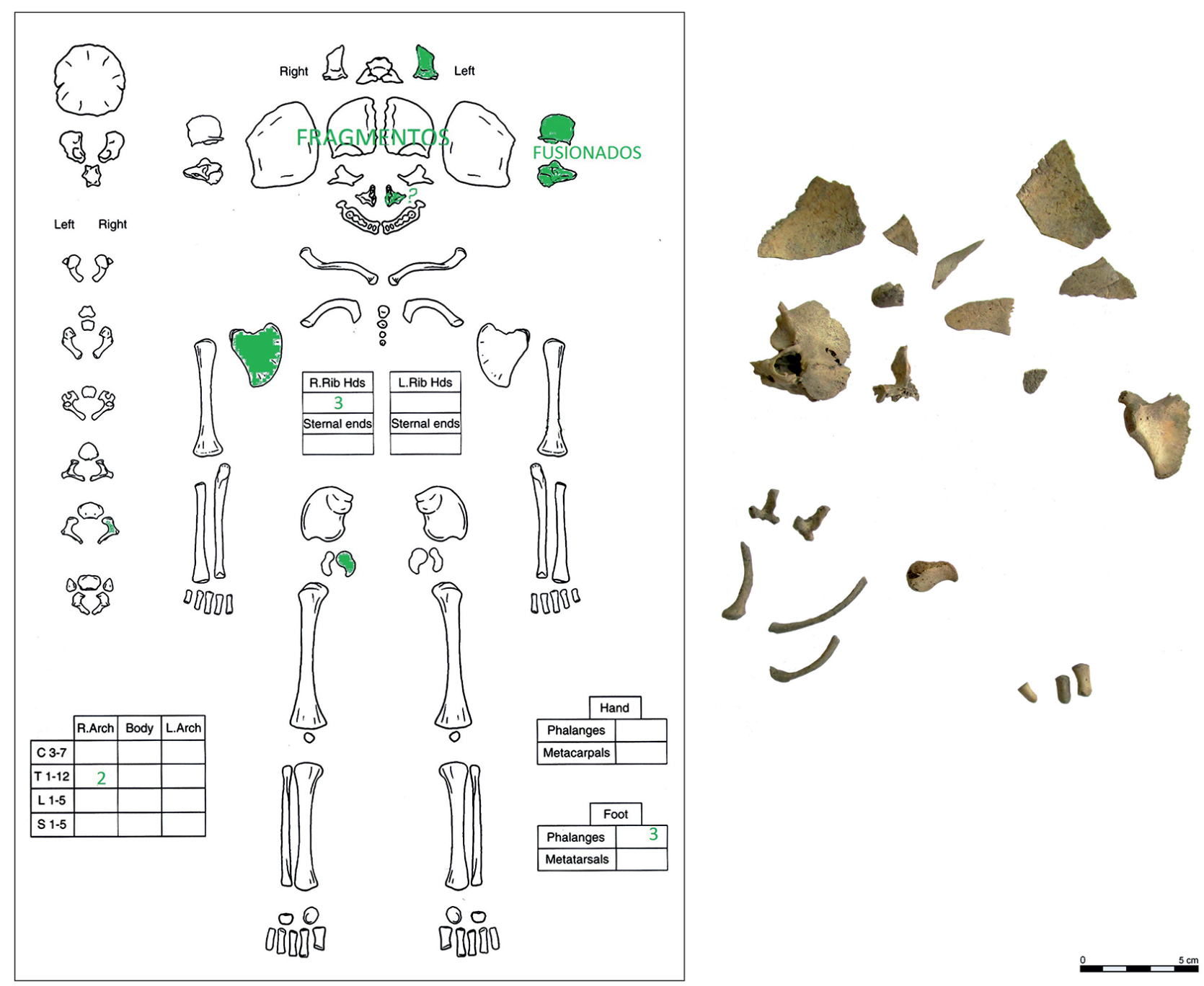

Fig.10. Skeletal remains of MB 2013. / Restos del sujeto MB 2013. 


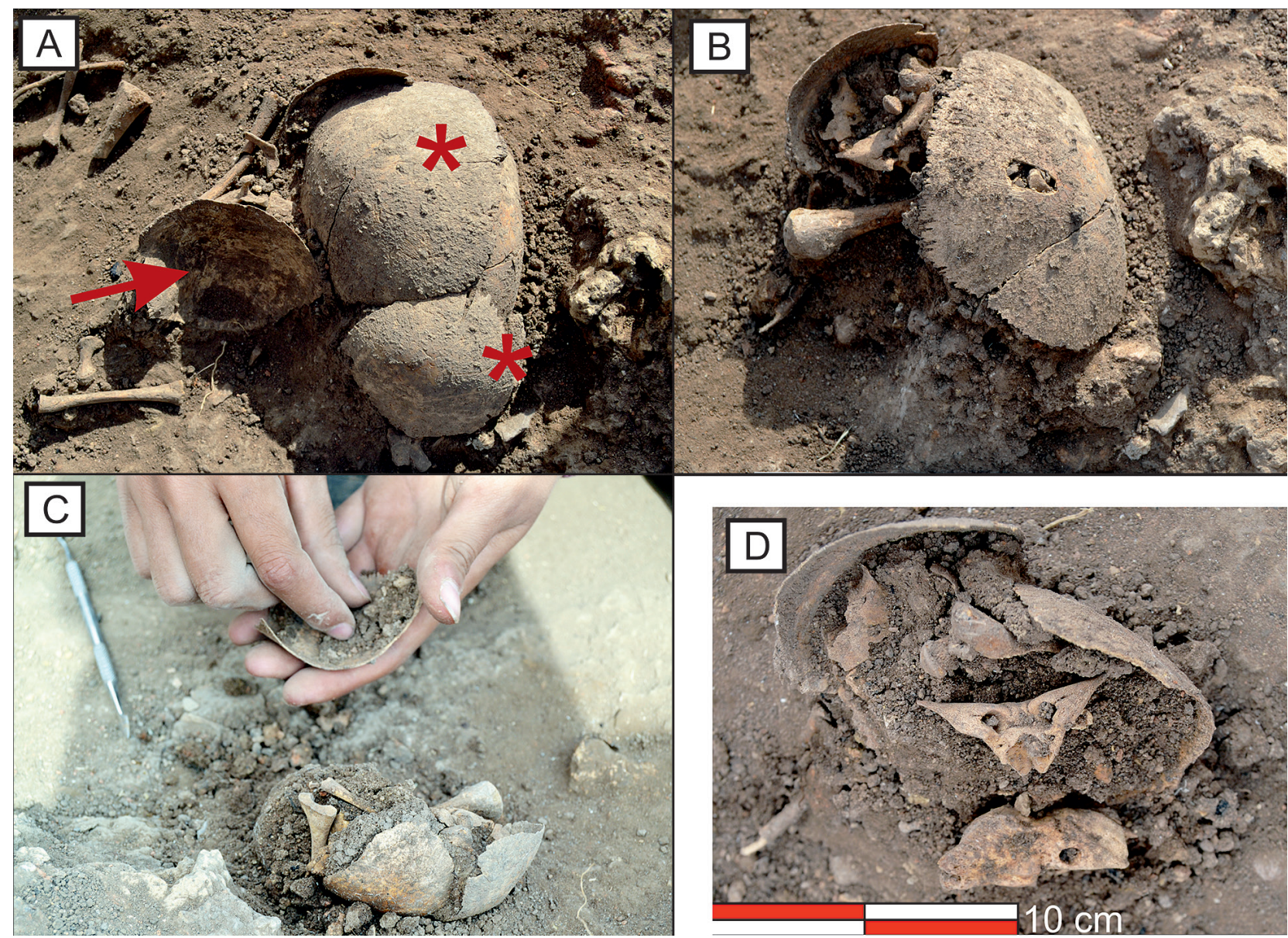

Fig.11. Skeletal remains exhumed during the archaeological season of 2016. Dispositions during the different phases. / Restos exhumados en la campaña de 2016. Disposición durante las distintas fases.

A: Red arrow: frontal bone of MB1/2016; asterisks, frontal bone of MB2/2016. / Flecha roja: frontal derecho perteneciente a MB1/2016; asteriscos, frontales de MB2/2016.

$\mathrm{B}$ : Bone aggregation after the removal of the frontal bones. The occipital of MB1/2016 is covering the remains of the long bones and the skull base. / Paquete óseo tras la retirada de los huesos frontales. Se observa el occipital de MB1/2016 cubriendo el resto de huesos largos y de la base de cráneo.

C: Bone aggregation after the removal of the MB1/2016 occipital bone. Long bones, taken over the occipital bone of MB2/2016, are shown. / Paquete óseo tras la retirada del hueso occipital de MB1/2016 Se observan huesos largos, recogidos sobre el occipital de MB2/2016.

$\mathrm{D}$ : Bone aggregation after the removal of the MB1/2016 occipital bone and a top view of the long bones. Several bones at the skull base, belonging to MB1/2016 and collected over the MB2/2016 occipital, are shown. / Restos del sujeto MB 2013. / Paquete óseo tras la retirada del hueso occipital de MB1/2016 y huesos largos, visión cenital. Se observan varios huesos de la base del cráneo, pertenecientes a MB1/2016 recogidos sobre el occipital de MB2/2016.

\subsubsection{2. $\mathrm{MB}-1 / 2016$}

Conservation: $25 \%$

Pathologies: None

Taphonomy: Roots marks, dry bone fractures. Post-depositional anthropic manipulation: frontal bones were at the top of the package; below them was the occipital of MB 1/2016 (fig. 11b). MB 2/2016 occipital was at the base and the rest of the bones (both cranial and postcranial) were located inside the package. Beside, other postcranial bones and MB 1/2016 frontal bone were also located, in a second set of osteological remains.

Sex: Undetermined

Age: 36 WG (34-36 WG).

\subsubsection{MB-3/2016}

Position of the skeletal remains: Among the remains of MB 1/2016.

Preserved bones: 2 pubis.

Age: 32-34 WG.

\subsubsection{MB-4/2016}

Preserved bones: A capital femoral epiphysis, (Fig. 12). Pathologies: Unidentified.

Taphonomy: Roots marks and erosion marks made by friction on its rim.

Age: 8 years old. 

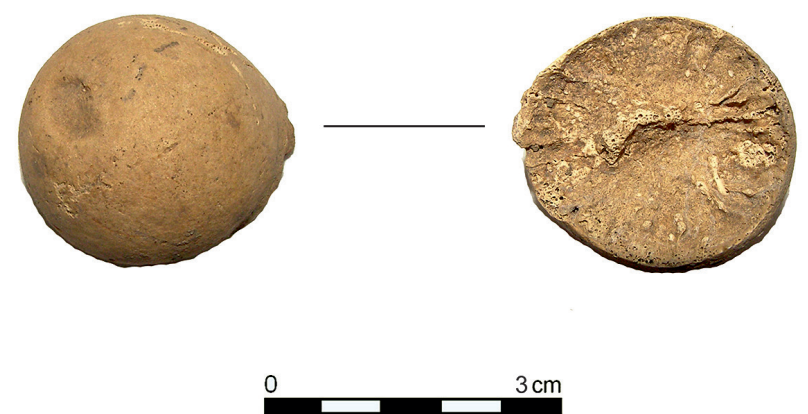

Fig.12. Capital femoral epiphysis of MB 4/2016. On the left, articular surface. In the right of the image, metaphyseal surface. / Epífisis proximal femoral del individuo MB 4/2016. Izquierda de la imagen, superficie articular. Derecha de la imagen superficie de fusión.

\section{DISCUSSION}

After the different osteoarcheological studies and revisions, the skeletal remains of ten subadult individuals have been identified: one adolescent, (MB-2/2007) died in the later stages of growth; a child about 8 years old (MB-4/2016), one aged 6 months to 1 year old (MB2013) and seven fetuses and/or perinates (MB-1/2006, MB-2/2006, MB-3/2006, MB-1/2007, MB-1/2016, MB$2 / 2016, M B-3 / 2016)$. All of them were buried in a small space of the oppidum, under the floor of two buildings near de center or the door.

This high concentration is consistent with the high infant mortality rates in past times, prior to the appearance of antibiotics and other hygienic-sanitary care. In any case, there are no reported anthropological studies from the necropolises of the oppidum, so until now there are no data about the total population of the oppidum to compare with. We even don't know if children were buried in them.

The absence of signs of violence suggests that they all died of natural causes, in accordance with the high pre- and perinatal mortality rate. Even at the present W.H.O. registers high infant mortality rates ${ }^{1}$. Regarding the causes of infant mortality: Most of the deaths of newborns (75\%) occur during the first week of life, and approximately 1 million newborns die in the first 24 hours of life. Premature deliveries, childbirth-related complications (including perinatal asphyxiation), neonatal infections, and birth defects caused the majority of newborn deaths in 2016. Since the end of the neonatal period and for the first 5 years of life, the main causes of death are pneumonia, diarrhea, birth defects, and malaria. Malnutrition is the underlying factor that exacerbates children's vulnerability to serious illness.
Based on these data, we can consider a similar situation for full-term perinates (MB-1/2006, MB-3/2006, $\mathrm{MB}-1 / 2007, \mathrm{MB}-1 / 2016$ and $\mathrm{MB}-2 / 2016)$, died during the delivery or at the immediate postpartum due to multiple causes: fetal suffering and perinatal asphyxia, metabolic diseases, infections, malnutrition, etc. The recovered bones show no signs of any malformation, although the existence of other types of congenital malformations incompatible with life, such as visceral malformations not visible on the bones, could be the cause.

MB 2/2016 (36 WG) would be considered a late premature, according to international recommendations (Rellán, 2008; Demestre Guach, 2009; Martín Pescador, 2019), and MB 3/2016 (32-34 WG), a younger premature. In addition to the risks associated with birth and the first months of life mentioned for full-term fetuses, the premature population is associated with greater morbidity and mortality. The lower the gestational age the greater the mortality, due to the immaturity of development (more than a third of neurological growth occurs between the 6th and 8th last weeks): lung immaturity related with greater respiratory problems; neurological immaturity that favors, among others, the appearance of apneas, difficulty in sucking and/or swallowing or thermal instability; endocrine immaturity, which facilitates the appearance of hypoglycemia (aggravated, as well, by the difficulty in swallowing and feeding capacity) (Demestre Guach, 2009).

However, it is impossible to know if some of these deaths correspond to infanticide and body concealment, since in many cases the mechanism to produce the death may not leave an osteological mark: suffocation, poisoning, stab wounds with no osseus injury, death by starvation or death by hypothermia brought on by exposure. Preliminary genetic studies carried in 6 individuals show an semiequal representation of both sex (3 females and 2 males), so we cannot include the selective infanticide of the females as hypothesis, attributed, without much anthropological basis, to other periods and cultures (Lewis, 2006). Nor do we have any data to guide a propitiatory sacrificial ritual, based on a Phoenician tradition, a hypothesis proposed by various authors but widely rejected today (Pellicer, 2008).

Taphonomy and archaeotanatology give clues to know the practiced ritual. Only few linear marks compatible with those caused by roots were detected. No weathering marks were identified, as well as scavenger marks or other marks produced by chemical or biological agents, so we assume they were always buried. It also indicates that the remains were always protected, perhaps in containers or wrapped in cloth. Dry bone

\footnotetext{
1 In 2017, some 2.5 million children died in their first month of life, that is, $47 \%$ of deaths of children under 5 years of age, an increase from the $40 \%$ registered in 1990. (...) In sub-Saharian Africa, which continues to be the region with the highest mortality rate for children under 5 years of age, the proportion of deaths of newborns it is relatively low (37\%). In contrast, in Europe, which has the lowest under-5 mortality rate, $54 \%$ of deaths of children under 5 occur in the neonatal period.
} 
fractures unrelated with trampling or archaeological work and attributed to compression of the soil were found. This treatment was made once the corpse was skeletonized: years after death, the remains, even from different children, were collected (and some of them, lost) and reburied. This is most evident in the case of the package excavated in the 2016 season in Building 2: the individuals were unearthed from the primary site once skeletonized, placed in a single set of two packages and reburied in the building; we suppose this such digging up/burials were made at several different times, leading to the loss of bones. We face a secondary bury, not the primary (Duday, 2009) and show an act of respect of this society for their weakest members.

Regarding the rite, the practice of child burials under the floor of houses has been documented in different sites since the Bronze Age, both in the Mediterranean and in Central Europe. The first infant burials within building structures were reported in Çatalhöyük (Konya, southern Anatolia, Turkey). In Europe, in the Neolithic site of Lepinski Vir (Iron Gates, Serbia) this type of practice is interpreted as a systematic ritual applied only to newborn infants (Stefanović-Borić, 2008). The ritual spread throughout the whole Balkans area and the Caucasus, since similar practices are detected at different moments in late Prehistory (Stefanović -Borić, 2008; Borić et al., 2014). At the beginning of the Bronze Age, we can find them in central and western Europe, along with the Yamanaya culture migration and other Indo-European groups (Anthony, 2007; Haak et al., 2015; Kristiansen et al., 2017; Olalde, 2019; Olalde et al., 2019). The identification of such rituals in the northwest of Spain in the Bronze Age is complicated due to the absence of extensive excavations in habitat type sites. However, we assume it is a Longue Durée phenomenon that has continued until contemporary times in this area (Barandiarán-Manterola, 1995, 1998; Fernández-Crespo, 2008; Torres-Martínez et al., 2012).

The reporting data would confirm the survival of an ancient funerary ritual, documented in other areas of the Iberian Peninsula and with no examples found in this area of the Cantabrian coast until now (see Table 1).

Until an anthropological study of the cremated remains of the associated necropolis is carried out we will not be able to determine whether this population group, fetuses and children, were also given other funerary treatments, as other authors suspect. Anyway, we clearly find an element of differentiation based on age. This would be rooted in a rite of passage established when the baby developed teething and could start feeding "by himself". In the words of Pliny the Elder (Nat Hist VII, 72.) "it is universal custom not to cremate a person before the teeth come out". The motivations for choosing one or the other, if this was the case, are beyond the anthropological interpretation of this study.

Concerning the recovered subadults, MB-2/2007 (adolescent) and MB-4/2016 (infans II), the interpreta- tion is more complex. Considering that the funeral rituals applied to the main population during the Iron Age is cremation, it is very difficult to explain the existence of these skeletal remains as well as their isolated appearance. MB-4/2016 is represented only by a capital femoral epiphysis, without malformations or evidence of other diseases. In any case, the age at the time of death (8 years old) is not a usual age of death in children: after birth, infant mortality increase between 2 and 4 years, due to traumatic causes given that children begin to lead a more independent life and face greater physical dangers. It has also been suggested that weaning and introduction of adult feeding may be a stressor (Lewis, 2006). After these years, subadult mortality decrease until the beginning of adulthood. Therefore, we are dealing with an individual deceased at an unusual stage of development. This, together with the fact that this ritual is not usually applied to subjects older than 1 year, suggests the population of Monte Bernorio and their own family included in a status similar to the 'immature' subjects in social terms, who needed home protection in the underworld. The accidental death hypothesis cannot be excluded, or even intentional death, with subsequent concealment of the body, but the archaeological context doesn't support it. MB-2/2007, however, is assumed as part of a victim of the Roman assault that destroyed the oppidum, since the bone appeared alone, outside the buildings and near the defensive wall.

Despite the fact the infant mortality rate can provide relevant information about the 'health' of the society we are studying, as well as the care provided to its members (Lewis, 2006), in our case it is very difficult to reach conclusions in this way, because we do not have any data related to the mortality of the oppidum inhabitants. In any case, the pattern suggested by Vögele for rural societies (1994; in Lewis, 2006), with higher mortality rates in the perinatal period (in our case, 7/9 recovered infants) than postnatal (2), seems to be confirmed. This sets a difference with industrial societies where environmental factors, and not endogenous factors (genetic diseases, maternal influences or other obstetric factors), have a greater influence on the mortality of children. In Atxa (Vitoria, Álava) 38 of the 49 neonatal burials were viable fetuses and nine had passed the birth and died between 1 and 10 months of age. Two children also reached 2 years of age, but were buried in the domestic environment (Filloy, 1995; Etxeberría-Herrasti, 1995). We can infer that in Monte Bernorio oppidum, once born, the children grew up in a protective environment and, most likely, they were breastfed (with the immunological benefit of this type of diet).

Despite the fragility intrinsic to the bones of perinatal subjects, their relative good state of preservation is striking (MB-1/2006, MB-2/2006, MB-3/2006, MB-1/2007, MB-1/2013, MB-1/2016, MB-2/2016 and MB-3/2016) compared with the infant (MB-4/2016) and subadult/young adult (MB-2/2007) subjects, giving an idea of the provided care by their relatives. 


\section{CONCLUSIONS}

The osteological remains of 10 subjects have been recovered, all of them subadults: one adolescent, one infans II, five infans I and three fetuses.

Given the excavated area, it is an Iron Age site with a high number of child burials in domestic environment. As Table 1 shows, Monte Bernorio oppidum is the only site in the western and central areas of the Cantabrian region with this type of osteological remains and one of the few with non-cremated human remains.

They were buried inside the buildings, in the protective domestic area, along with a widely spread funerary ritual in European region as a true phenomenon of Longue Durée. In the case of the infans II subject (MB4/2016) we can propose the hypothesis he could be affected by a serious disease and so cared until and after his death. Therefore Monte Bernorio oppidum inhabitants would not consider them as full-fledged members, assimilating them with non-teethed children (edentulous). This would open an interesting debate and new perspectives on the consideration of child life and care in this culture and this historical moment.

In some cases, this protection or preservation of the skeletal remains seems to involve several generations, as some findings suggest: the package of different skeletons (more evident in 2016 season recoveries) and the progressive bone loss due to natural degradation as well as re-location of the remains over the years. The stratigraphic situation, location and way they appeared suggest the remains were recovered during the reconstruction of the buildings, regrouped and reburied under the new construction. The confirmation of this hypothesis means these remains had an important ritual consideration, so important care was taken to reintegrate them into the domestic construction space. Even more, it could imply same family lineages occupied same spaces for very long periods of time, probably centuries, rebuilding and reforming same homes over the time.

Concerning the cause of death, no injuries that support a violent death were found in the bone remains. However, such a death cannot be categorically ruled out since some fatal injuries do not damage bones (suffocation or stab wounds that affect vital organs, for example). In the same way, given the absence of osteological signs, infanticide in any of its forms, active or passive (abandonment or exposure of the newborn and deprivation of basic care) cannot be sustained either denied. Although this practice has been carried out throughout history as demographic control, it is not plausible a not loved alive member could be welcomed in such a preferred place at home after death. Everything indicates children buried in the rear of the houses at the Monte Bernorio oppidum died of natural causes during their pregnancy, childbirth, postpartum or in the first months of life, as happens today due to the high morbidity and mortality rate suffered by this population group.
This is also seen in the care expressed in the recovery of their remains over time during the rebuildings.

\section{REFERENCES}

Anthony, D. W., 2007. The Horse, the Wheel, and Language: How Bronze-Age Riders from the Eurasian Steppes Shaped the Modern World. Princeton University Press, Oxfordshire.

Armendáriz Martija, J., De Miguel Ibáñez, M. P., Anthony, D. W., 2006. Los enterramientos infantiles del poblado de Las Eretas. Estudio paleoantropológico. Trabajos de Arqueología Navarra 19, 5-44

Armendáriz Martija, J., 1996: Poblado de Las Eretas (Berbinzana). Campañas de 1994, 1995 y 1996. Trabajos de Arqueología de Navarra 12. 298-303

Armendáriz Martija, J., 2007. De 0 a 3 meses. Los enterramientos infantiles en el poblado de Las Eretas (Berbinzana). En: La tierra te sea leve. Arqueología de la Muerte en Navarra. Catálogo de la Exposición, 115-119. Gobierno de Navarra, Pamplona.

Ayala, M., Jiménez, S., Malgosa, A., Alessan, A., Safont, S., 1999. Los enterramientos infantiles en la prehistoria reciente del Levante y sureste peninsular. Anales de Murcia 15, 15-77.

Barandiaran, J. M., De Manterola, A., 1995. Ritos funerarios en Vasconia. Atlas etnográfico de Vasconia. Grupo Etniker, Eusko Jaurlaritza y Gobierno de Navarra, Bilbao.

Barandiaran, J. M., De Manterola, A., 1998. Ritos del nacimiento al matrimonio: Atlas etnográfico de Vasconia. Grupo Etniker, Eusko Jaurlaritza y Gobierno de Navarra, Bilbao.

Barberá, J., Campillo, D., Miró, C., Molist, N., 1989. Las inhumaciones infantiles y otros ritos en el poblado ibérico de la Penya del Moro de Sant Just Desvern (Barcelona). Cuadernos de Prehistoria y Arqueología Castellonenses (Ejemplar dedicado a: Inhumaciones infantiles en el ámbito mediterráneo español (siglos VII a.E. al II d.E.) 14,161-172.

Bermúdez De Castro, J. M., 1992: Apéndice 3. Informe sobre un esqueleto infantil hallado en el yacimiento de La Coronilla (Chera, Guadalajara). En: Cerdeño, M.K., García, R. El castro de La Coronilla. (Chera, Guadalajara) (1980-86), 137-139. Excavaciones Arqueológicas en España 163. Instituto de Conservación y Restauración de Bienes Culturales. Ministerio de Cultura, Madrid.

Bettencourt, A.M.S., 2010. Burials, corpses and offerings in the Bronze Age of NW Iberia as agents of Social Identity and Memory. In: Bettencourt, A.M.S., Sanches, M.J., Alves, L.B., Fábregas Valcarce, R. (Eds.). Conceptualising Space and Place. Proceedings of the XV World Congress of the IUPPS, 33-45. BAR International Series, 2058. Oxford.

Bettencourt, A.M.S., 2010. La Edad del Bronce en el Noroeste de la Península Ibérica: un análisis a partir de las prácticas funerarias. Trabajos de Prehistoria 67(1), 139-173. doi: 10.3989/ tp.2010.10034

Buikstra, J.E., Ubelaker, D.H., 1994. Standards for data collection from human skeletal remains. Arkansas Archeological Survey Research series 44

Boric, D., French, C. A. I., Stefanović, S., Dimitrijević, V., Cristiani, E., Gurova, M., Antonović, D. Allué, E. A., Filipović, D., 2014. Late Mesolithic lifeways and deathways at Vlasac (Serbia). Journal of Field Archaeology 39(1), 4-31. 
Botella, M.C., Alemán, I., Jiménez, S.I., 2000. Los Huesos Humanos: Manipulación y Alteraciones. Barcelona.

Campillo, D., Eulália Subirá, M., 2004. Antropología Física para Arqueólogos. Ariel, Barcelona.

Cerdeño, M. L., García, R., 1987. Estructuras de habitación del poblado de La Coronilla (Molina de Aragón, Guadalajara). Zephyrus 39-40, 337-345.

Cerdeño, M. L., García, R., 1992. El castro de La Coronilla. (Chera, Guadalajara) (1980-86). Excavaciones Arqueológicas en España 163. Instituto de Conservación y Restauración de Bienes Culturales. Ministerio de Cultura, Madrid.

Cerdeño, M. L., Sagardoy, T., 2007. La necrópolis celtibérica de Herrería III y IV (Guadalajara). Estudios Celtibéricos 4. Fundación Segeda-Centro de Estudios Celtibéricos y Junta de Castilla La Mancha Eds, Zaragoza.

Cerdeño, M. L., Sagardoy, T., 2016. La necrópolis celtibérica de Herrería I y II. Las fases culturales del Bronce Final II-III. La Ergástula Ediciones, Madrid.

Chapa, M.T., 2003. La percepción de la infancia en el mundo ibérico. Trabajos de Prehistoria, Vol. 60(1), 115-138.

De Miguel Ibáñez, M. P., 2009. Las inhumaciones perinatales de El Castejón de Bargota (Navarra). Cuadernos de Arqueología Universidad de Navarra 17, 229-248.

De Miguel Ibáñez, M. P., 2010. Una visión de la infancia en la osteoarqueología: de la Prehistoria reciente a la Edad Media. Complutum 21(2), 135-154.

Demestre Guasch, X., Raspall Torrent, F., Martínez-Nadal, S., Vila Cerén, C., Elizari Saco, M.J., Sala Castellví, P., 2009. Prematuros tardíos: una población de riesgo infravalorada. Anales de Pediatría (Barc) 71(4), 291-298.

Duday, H., 2009. The archaeology of the death. Lectures in Archaeothanatology. Oxbow books 89-93.

Etxeberria, F., Herrasti, L., 1995. El análisis antropológico de las inhumaciones de Atxa. En: Gil Zubillaga, E. (Dir.), Atxa: Memorias de las excavaciones arqueológicas 1982-1988, 423-426. Departamento de Cultura, Diputación Foral de Álava, Vitoria.

Fábregas, R., 1995. La realidad funeraria en el Noroeste del Neolítico a la Edad del Bronce. In: Fábregas, R., Pérez Losada, F., Fernández Ibáñez, C. (Ed.), Arqueoloxía da Muerte na Península Ibérica desde as Orixes ata o Medievo, 95-125. Universidad de Vigo, Xinzo de Limia.

Fábregas, R., Ruiz-Gálvez, M., 1994. Ámbitos funerario y doméstico en la Prehistoria del NO. de la Península Ibérica. Zephyrus 46, 143-160.

Fábregas, R., Bradley, R., 1995. El silencio de las fuentes: prácticas funerarias en la Edad del Bronce del Noroeste y su contexto europeo. Complutum 6, 153-166.

Fábregas, R., Ruiz-Gálvez, M., 1994. Ámbitos funerario y doméstico en la Prehistoria del NO. de la Península Ibérica. Zephyrus 46, 143-160.

Fernández Crespo, T., 2008. Los enterramientos infantiles en contextos domésticos en la Cuenca Alta/Media del Ebro: a propósito de la inhumación del despoblado altomedieval de Aistra (Álava) Munibe Antropologia-Arkeologia 59, 199-217.

Fernández-Götz, M., 2014. Understanding the Heuneburg: A Biographical Approach. In: Fernández-Götz, M., Wendling, H., Winger, K. (Eds.), Paths to Complexity: Centralisation and Urbanisation in Iron Age Europe, 24-34. Oxbow Books, Oxford.
Fernández-Jalvo, Y., Andrews, P., 2016. Atlas of Taphonomic Identifications. 1001+ images of fossil and recent mammal bone modifications. Springer.

Filloy, I., Gil De Zubillaga, E., 1992. Atxa, poblado indígena y campamento militar romano. Museo de Arqueología de Álava, Vitoria.

Filloy Nieva, I., 1995. Los enterramientos infantiles. En: Gil Zubillaga, E. (Dir.), Atxa: Memorias de las excavaciones arqueológicas 1982-1988, 171-189. Departamento de Cultura, Diputación Foral de Álava, Vitoria.

Galilea, F., García, A., 2002. Enterramientos infantiles en el poblado protohistórico de La Hoya (Laguardia. Alava). Estudios de Arqueología Alavesa 19, 150-162.

Guerin, P., Martínez, R., 1988. Inhumaciones infantiles en poblados ibéricos del área valenciana. Saguntum 21, 231-266.

Gibaja, J.F., Majó, T., Chambon, P., Ruíz, J., Subirá, M. E., 2010. Prácticas funerarias durante el neolítico. Los enterramientos infantiles en el noreste de la Península Ibérica. Complutum 21(2), 47-68.

Gómez Bellard, F., 2016. Anexo 1. Estudio de las cremaciones. La necrópolis celtibérica de Herrería I y II. En: Cerdeño, M. L., Sagardoy, T. (Ed.), Las fases culturales del Bronce Final II-III, 257-264. La Ergástula Ediciones, Madrid.

Gómez Osuna, R., 2018. Enterramientos Infantiles Altomedievales en La Cabilda, Hoyo de Manzanares. Territorio, sociedad y poder: revista de estudios medievales 13, 22-47.

González Morales, M. R., 1999. La Prehistoria Reciente. En: Cántabros, la génesis de un pueblo. Catálogo de la Exposición. Santillana del Mar, Museo Diocesano Abril-Octubre, 6193. Comisión del Centenario de Caja Cantabria, Santander.

Gusi, F., 1989. Posibles recintos necrolátricos infantiles ibéricos en Castellón. Quaderns de prehistòria i arqueologia de Castelló 14, 19-42.

Gusí, F., Muriel, S., 2008. Panorama Actual de la Investigación de las Inhumaciones infantiles en la protohistoria del sudoeste mediterráneo europeo. En: Nasciturus, infans, puerulus vobis mater terra: la muerte en la infancia, 257-330.

Gusí, F., Luján, J., 2011. Enterramientos infantiles y juveniles edad Bronce peninsular. Una aproximación cuantitativa. Quaderns de prehistòria i arqueologia de Castelló 29, 153-208.

Gutiérrez Cuenca, E., Hierro Gárate, J., 2016. Ángel de los Ríos y la primera exploración científica de Monte Bernorio. Sautuola XXI, 11-17.

Haak, W., Lazaridis, L., Patterson, N., Rohland, N., Mallick, S., Llamas, B., Brandt, G., Nordenfelt, S., Harney, E., Stewardson, K., Fu, Q., Mittnik, A., Bánffy, E., Economou, C., Francken, M., Friederich, S., Garrido Pena, R., Hallgren, F., Khartanovich, V., Khokhlov, A., Kunst, M., Kuznetsov, P., Meller, H., Mochalov, O., Moiseyev, V., Nicklisch, N., Pichler, S. L., Risch, R., Rojo Guerra, M. A., Roth, C., Szécsényi-Nagy, A., Wahl, J., Meyer, M., Krause, J., Brown, D., Anthony, D., Cooper, A., Werner Alt, K., Reic.h, D., 2015. Massive Migration From The Steppe Was A Source For Indo-European Languages In Europe. Nature 522 (7555) (March). 207-211. DOI: 10.1038/nature14317

Irurita Olivares, J., Alemán Aguilera, I., 2016. Validation of the sex estimation method elaborated by Schutkowski in the Granada Osteological Collection of identified infant and young children: Analysis of the controversy between the different ways of analyzing and interpreting the results. International Journal of Legal Medicine 130(6), 1623-1632. 
Jimeno, A., De La Torre, J. I., Berzosa, R., Martínez, J. P., 2004 La necrópolis celtibérica de Numancia. Arqueología en Castilla y León 12, Memorias. Junta de Castilla y León, Valladolid.

Jover-Maestre, F.J., Martínez Monleó, S., De Miguel Ibáñez, M.P., López Padilla, J.A., Torregrosa Giménez, P., Pastor Quiles, M., Basso Rial, R., 2018. ¿Violencia Física o accidente? Nuevos datos sobre el enterramiento infantil del asentamiento argárico de Caramoro I (Elche, Alicante, Spain). Arqueología iberoamericana 38, 25-31.

Krogman, W.M., Iscan, M.Y., 1986. The Human Skeleton in Forensic Medicine. Charles C. Thomas Publisher. Springfield, Illinois.

Lewis, M., 2006. The bioarcheology of children. Perspectives from biological and forensic Anrthropology. Cambridge University Press.

Lewis, M., 2018. Paleopathology in Children. Identification of paleopathological conditions in the human skeletal remains of non-adults. Academic Press. Elsevier.

Lorrio, A.J., De Miguel Ibáñez, M. P, Moneo, T., Sanchez De Prado, M.D., 2010. Enterramientos infantiles en el "oppidum" de El Molón (Camporrobles, Valencia). Cuadernos de Arqueología de la Universidad de Navarra 18, 201-262.

Llanos, A., 1990. La Edad del Hierro y sus precedentes en Álava y Navarra. Munibe Antropologia-Arkeologia 42, 167-179.

Llanos, A., 2002. Gentes del Hierro en privado. La casa en la Edad del Hierro en Álava. Museo de Arqueología de Álava, Exposiciones $\mathrm{N}^{\circ}$ 02, Vitoria.

Llanos, A., 2005. Mil años de vida en el poblado berón de La Hoya (Laguardia-Álava). Guía del Yacimiento y del Museo. Servicio de Publicaciones Departamento de Cultura Juventud y Deportes, Diputación Foral de Álava, Vitoria.

Maluquer, J., 1958. El yacimiento hallstattico de Cortes de Navarra. Estudio crítico, Vol. II. Excavaciones en Navarra VI. Pamplona.

Maluquer, J., García, F., Munilla, G., 1990. Alto de la Cruz (Cortes, Navarra). Campañas, 1986-1988. Trabajos de Arqueología de Navarra 9. Pamplona.

Martin Peinador, Y., Soriano Faura, J., Garcia Reymundo, M., Hurtado Suazo, J.A., Calvo Aguilar, M.J., Ginovart Galiana, G. Jimenez Moya, A., Demestre Guasch, X., 2019. El prematuro tardío: evolución y recomendaciones de seguimiento. Pediatria Integral XXIII(3). CURSO VI.

Maya, J.L., Cuesta, F., 1992A. Excavaciones en La Campa Torres (1986-1999). Excavaciones Arqueológicas en Asturias 1987-1990, 145-152.

Maya, J.L., Cuesta, F., 1992B. El castro de La Campa Torres. In: Fernandez Miranda(Ed), Los Orígenes de Gijón, 36-52.

Maya, J.L., Cuesta, F., 1995. Primeros resultados de los niveles prerromanos de La Campa Torres (Gijón, Asturias). En: Actas del XXII Congreso Nacional de Arqueología. 1993 Xunta de Galicia, Consellería de Cultura, Dirección Xeral de Patrimonio Histórico e Documental, Vol.1, 93-100. Vigo.

Maya, J.L., Cuesta, F., 2001. El castro de la Campa Torres. Periodo Prerromano.

Meijide Cameselle, G., 1994. El concepto de las relaciones atlánticas en la Edad del Bronce del Noroeste. En: Reboreda Morillo, S., Castro Pérez, L. (Coords), Edad del Bronce. Actas del Curso de Verano de la Universidad de Vigo, 1993, 195232. Xixo de Limia.
Mercadal, O., Campillo, D., Pérez-Pérez, A., 1990. Estudio Paleoantropológico de los restos infantiles del Alto de la Cruz. Campañas 3/1987 y 4/1988. Alto de la Cruz (Cortes, Navarra). Campañas, 1986-1988. Trabajos de Arqueología de Navarra 9, 219-243

Mercadal, O., Fernandez, I., 2001. Estudio Paleoantropológico de dos restos óseos procedentes del yacimiento arqueológico de La Campa Torre. En: Maya, J. L., Cuesta, F. (eds.), El castro de la Campa Torres. Periodo Prerromano, 295-296. Gijon.

Munilla, G., Campillo, D., Mercadal, O., Gracia, F., 1989. Enterramientos infantiles en el poblado ibérico de la Moleta del Remei (Alcanar, Montsia). Cuadernos de Prehistoria y Arqueología Castellonenses (Ejemplar dedicado a: Inhumaciones infantiles en el ámbito mediterráneo español (siglos VII a.E. al II d.E.) $14,133-160$.

Navarro García, R., 1939. Catálogo Monumental de la Provincia de Palencia. Partidos de Cervera del Río Pisuerga y Saldaña. Diputación Provincial de Palencia.

Olalde, I., 2019. The Beaker phenomenon and the genomic transformation of northwest Europe. Nature 555, 190-196.

Olalde, I. Mallick, S., Patterson, N, Rohland, N., Villalba-Mouco, V.Silva, M., Dulias K., Edwards, C.J., Gandini, F., Pala, M. Soares, P. Ferrando-Bernal, M., Adamski, N., Broomandkhoshbacht, N., Cheronet, O., Culleton, B.J., Fernandes, D., Lawson, A. M., Mah, M., Oppenheimer, J., Stewardson, K., Zhang, Z., Jiménez Arenas, J. M. Toro Moyano, I. J., Salazar-García, D.C., Castanyer, P., Santos, M., Tremoleda, J., Lozano, M., García Borja, P., Fernández-Eraso, J., Mujika-Alustiza, J. A., Barroso, C., Bermúdez, F. J., Viguera Mínguez, E., Burch, J., Coromina, N., Vivó, D., Cebrià, A., Maria Fullola, J.M., García-Puchol, O., Morales, J.I., Oms, F.J., Majó, T., Vergès, J.M., Díaz-Carvajal, A.,Ollich-Castanyer, I., López-Cachero, Fj., Silva A.M., Alonso-Fernández, C., Delibes De Castro, G., Jiménez Echevarría, J., Moreno-Márquez, A., Pascual Berlanga, G., Ramos-García, P., Ramos-Muñoz, J., Vijande Vila, E., Aguilella Arzo, G., Esparza Arroyo, A., Lillios, K. T., Mack, J., Velasco-Vázquez, J., Waterman, A., Benítez De Lugo Enrich, L., Benito Sánchez, M., Agustí, B., Codina, F., De Prado, G., Estalrrich, A., Fernández Flores, A., Finlayson, C., Finlayson, G., Finlayson, S., Giles-Guzmán, F., Rosas A., Barciela González, V., García Atiénzar, G., Hernández Pérez, M. S., Llanos, A., Carrión Marco, Y., Collado Beneyto, I., López-Serrano, D., Sanz Tormo, M., Valera, A. C., Blasco, C., Liesau, C., Ríos, P., Daura, J., De Pedro Michó, M. J., Diez-Castillo, A. A., Flores Fernández, Raúl, Francès Farré, J., Garrido-Pena, R., Gonçalves, V. S., Guerra-Doce, E., Herrero-Corral, A. M., Juan-Cabanilles, J., López-Reyes, D.,Mc Clure, S. B., Merino Pérez, M., Oliver Foix, A., Sanz Borràs, M., Catarina Sousa, A., Vidal Encinas, J.M., Kennett, D. J., Richards, M. B., Werner Alt, K, Haak, W., Pinhasi, R., Lalueza-Fox, C., Reich, D., 2019. The genomic history of the Iberian Peninsula over the past 8000 years. Science 363(6432), 1230-1234

Pellicer Catalán, M., 2008. Los inicios del rito funerario de incineración en la Península Ibérica. Revista Tabona 16, 13-35.

Prados, L., 2012. El ritual funerario durante la II Edad del Hierro en la Península Ibérica. Algunas reflexiones sobre los grupos marginados por la investigación. Cuadernos de Prehistoria y Arqueología 37-38, 317-332.

Rellan Rodríguez, S., Garcia De Ribera, C., Aragón Garcia, M.P., 2008. El recién nacido prematuro. Protocolos Diagnóstico Terapeúticos de la AEP: Neonatología. Protocolo. Asociación Española Pediatría.

Rodríguez González, C., 2015. Arqueología de la infancia: niños y niñas en la Prehistoria Reciente de la región de Murcia a través de los restos funerarios. Arqueología y territorio 12, 49-62. 
Ruiz Cabrero, L.A. 2008. Costumbres fenicias en ámbitos indígenas: los enterramientos infantiles en lugares de producción. Contactes. Indígenes i fenicis a la Mediterrània occidental entre els segles VIII i VI ane. Ajuntament d'Alcanar / Signes disseny i comuncació.

Ruiz-Gálvez, M., 1998. La Europa Atlántica en la Edad del Bronce. Un viaje a las raíces de Europa Occidental. Crítica Arqueología. Ed. Crítica Grijalbo Mondadori, Barcelona.

Ruiz-Zapatero, G., Lorrio Alvarado, A. J., 1995. La muerte en el norte Penínsular durante el Primer Milenio. En: Fábregas, R. Pérez, F., Fernández, C. (Eds), Arqueología da morte na Península Ibérica desde as orixes ata o Medievo, 223-248. Xinzo de Limia.

Schaefer, M., Black, S., Scheuer, L., 2009. Juvenile Osteology. A laboratory and field manual. Ed. Elsevier.

Scheuer, L., Black, S., 2000. Developmental Juvenile Osteology. Ed. Elsevier.

Stefanović, S., Borić, D., 2008. New-born infant burials underneath house floors at Lepenski Vir: in pursuit of contextual meanings. In: Bonsall, C., Boroneant, V., Radovanovic, I. (Eds.), The Iron Gates in Prehistory: New Perspectives, 131-169. BAR International Series 1893. Archaeopress, Oxford.

Teira Mayolini, L. C., 1994. El Megalitismo en Cantabria. Aproximación a una realidad arqueológica olvidada. Servicio de Publicaciones, Universidad de Cantabria, Santander.

Tilley, L., 2015. Theory and Practice in the Bioarcheology of Care. Springer.

Torija, A., Baquedano, I., Cruz, M., 2009. Inhumaciones infantiles en el centro peninsular durante la protohistoria. Algunas novedades en el yacimiento de Cerrocuquillo. En: VI Simposio sobre Celtiberos. Ritos y Mitos, 433-444. Fundación Segeda.
Torres-Martínez, J. F., 2011. El Cantábrico en la Edad del Hierro. Medioambiente economía, territorio y sociedad. Col. Bibliotheca Archaeológica Hispana 34. Gabinete de Antigüedades de la Real Academia de la Historia, Madrid.

Torres-Martínez, J.F., Domínguez-Solera, S.D., Carnicero-Cáceres, S., 2012. Inhumaciones de perinatales en el área de la muralla sur del oppidum de Monte Bernorio (Villarén, Palencia). Ritos de edad y rituales funerarios. Munbe Antropologia-Arkeologia 63, 199-211.

Torres-Martínez, J. F., Martínez Velasco, A., Serna Gancedo, M. L., 2013. El oppidum de Monte Bernorio (Villarén, Palencia) Una ciudad fortificada de la Edad del Hierro en la Montaña Palentia. Colección de Historia de la Montaña Palentina 7, 11-86.

Torres-Martínez, J.F., Fernández-Götz, M., Martínez-Velasco, A., Vacas-Madrid. D., Rodríguez-Millán, E., 2016. From the Bronze Age to the Roman Conquest: the Oppidum of Monte Bernorio (Northern Spain). In: Proceedings of the Prehistoric Society Vol. 82, 363-382.

Torres-Martínez, J.F., Fuentes-Domínguez, A., Domínguez-Solera, S.D., Rodríguez-Trigo, A., Hamann, C., Fernandes, R., Martínez-Velasco, A., Serna-Gancedo, A., Sobremazas-Martínez, J.M., 2017. El fenómeno funerario en la Edad del Hierro del Cantábrico. Un nuevo espacio ritual en la necrópolis de Monte Bernorio (campañas de excavación de 2007 y 2008). Lucentum 36, 105-128.

White, T., Black, M., Folkens, P., 2012. Human Osteology. Academic Press. Elsevier.

W.H.O. Data update available at https://www.who.int/es/ news-room/fact-sheets/detail/reducir-la-mortalidad-de-los-recién-nacidos. 